\title{
Carbon Monoxide Poisoning in a Neonate
}

\author{
Swetha Palla ${ }^{1} \cdot$ Jogender Kumar $^{1}$ (D) $\cdot$ Altaf Hussain $^{1} \cdot$ Kanya Mukhopadhyay $^{1}$
}

Received: 7 February 2019 / Accepted: 27 February 2019 /Published online: 9 March 2019

(C) Dr. K C Chaudhuri Foundation 2019

To the Editor: Carbon monoxide ( $\mathrm{CO}$ ) poisoning in a neonate is an uncommon and unrecognized entity. It poses higher risk to neonates than adults and older children due to non-specific clinical presentation and higher levels of fetal hemoglobin $(\mathrm{HbF})$ in neonates. We report an unusual case of $\mathrm{CO}$ poisoning in a neonate.

A 14-d-old, previously healthy boy was brought to emergency with complaints of decreased responsiveness, poor feeding and multiple episodes of vomiting for $4 \mathrm{~h}$. There was a history of exposure to room heating coal furnace in a closed room for 4-5 h. Mother and grandmother also experienced headache and fell unconscious. They regained consciousness after $2-3 \mathrm{~h}$ and noticed that the baby is dull and unresponsive and brought him to the hospital. There was no history of seizures. Baby was hemodynamically stable and blood gas revealed $\mathrm{pH}-7.24, \mathrm{pCO}_{2}-37.2, \mathrm{pO}_{2}-45.5, \mathrm{SO}_{2}$ $-87.4 \%$, carboxy hemoglobin $(\mathrm{COHb})-10.6 \%$ and lactate $-10.6 \mathrm{mmol} / \mathrm{L}$. In view of elevated $\mathrm{COHb}$ and $\mathrm{h} / \mathrm{o}$ recent exposure, possibility of $\mathrm{CO}$ poisoning was considered and baby was started on $100 \%$ oxygen therapy and intravenous fluids. After 3-4 h he started regaining consciousness and by $8 \mathrm{~h}$ he became normal. Repeat blood gas at $8 \mathrm{~h}$ showed $\mathrm{pH}-$ $7.43, \mathrm{COHb}-0.1 \%$ and lactate $-4.5 \mathrm{mmol} / \mathrm{L}$. Oxygen was stopped and breastfeeding was initiated. Baby was discharged after a total stay of $24 \mathrm{~h}$.

$\mathrm{CO}$ poisoning is a sequel of fires and accidents with home heating appliances powered by oil, coal or wood [1]. The mechanism of $\mathrm{CO}$ toxicity predominantly relates to tissue hypoxia [2]. As compared to oxygen, $\mathrm{CO}$ has 240 times more affinity to hemoglobin leading to displacement of oxygen and reduction of blood oxygen. Also, it's binding to $\mathrm{Hb}$ causes left shift of the oxygen dissociation curve. In neonates, due to high $\mathrm{HbF}$, the curve already has left shift and hence, hypoxia is more pronounced [3]. History of exposure along with measurement of $\mathrm{COHb}$ is diagnostic, however, in hemolytic jaundice, $\mathrm{COHb}$ may be falsely elevated [4]. Removal from the exposure and administration of oxygen is the key for management. Four to six hours of oxygen will remove over $90 \%$ of the $\mathrm{CO}$. Treatment is recommended until $\mathrm{COHb}$ reaches normal $(<3 \%)$.

\section{Compliance with Ethical Standards}

Conflict of Interest None.

Publisher's Note Springer Nature remains neutral with regard to jurisdictional claims in published maps and institutional affiliations.

\section{References}

1. Unsal Sac R, Taşar MA, Bostancı İ, Şimșek Y, Bilge Dallar Y. Characteristics of children with acute carbon monoxide poisoning in Ankara: a single centre experience. J Korean Med Sci. 2015;30: 1836-40.

2. Chiew AL, Buckley NA. Carbon monoxide poisoning in the 21st century. Crit Care. 2014;18:221.

3. Venning H, Roberton D, Milner AD. Carbon monoxide poisoning in an infant. Br Med J (Clin Res Ed). 1982;284:651.

4. Bailey DGN, Fuchs H, Hentschel R. Carboxyhemoglobin - the forgotten parameter of neonatal hyperbilirubinemia. J Perinat Med. 2017;45:613-7.

Jogender Kumar

jogendrayadv@gmail.com

1 Department of Pediatrics, Post Graduate Institute of Medical Education and Research, Chandigarh 160012, India 